\title{
Heavy metals bioaccumulation and histopathological changes in Auchenoglanis occidentalis fish from Tiga dam, Nigeria
}

\author{
Samson Eneojo Abalaka
}

\begin{abstract}
The assessment of heavy metals concentration in Tiga dam, Nigeria vis-à-vis their bioaccumulation and histopathological alterations in Auchenoglanis occidentalis from it were carried out. The water of the dam and the liver of the fish were analyzed for zinc ( $\mathrm{Zn})$, cadmium (Cd), lead (Pb) and iron (Fe) concentrations and their bioaccumulation factors. At the same time, the gills, liver and kidney of the exposed fish were also examined for histopathological alterations. The results revealed that concentrations of the metals differs significantly $(p<0.05)$ between the dam's water and the liver of the sampled fish. Liver bioaccumulations of the metals were in the order of $\mathrm{Zn}>\mathrm{Fe}>\mathrm{Cd}>\mathrm{Pb}$. However, the degree of tissue alterations in the gills showed their normal functioning despite the observed alterations while liver and kidney were mildly and moderately damaged, respectively. This indicated that $\mathrm{Zn}, \mathrm{Cd}, \mathrm{Pb}$ and Fe polluted the dam.
\end{abstract}

Keywords: Auchenoglanis occidentalis, Heavy metals, Bioaccumulation, Histopathology

\section{Introduction}

Pollution of aquatic environment is a serious and growing problem [1], which is usually brought about by increasing domestic, agricultural, commercial and industrial activities of man [2]. However, heavy metals are considered the most hazardous of all environmental pollutants [3] due to their bioaccumulation and toxicity tendency [4]. This is because heavy metals may precipitate, get absorbed on sediment particles, remain soluble or suspended in water and/or may be taken up by aquatic fauna upon their entry into water bodies $[5,6]$. Metals are then absorbed through gills and skin and/or ingested through food to cause bioaccumulative toxicity in fish where the intensity of the toxicity is influenced by the temperature, oxygen concentration, $\mathrm{pH}$ and hardness of the water [7]. Tiga dam is a huge water reservoir on Kano River in northern part of Nigeria, which is an important source of fish and water for drinking and irrigation of surrounding farm lands.

Though it derives its water source from the Jos highlands, which is known for its mining activities, it flows towards the Hadejia-Nguru wetlands through Kano to empty into Lake Chad. Therefore, there is a need to assess the

Correspondence: seabalaka@yahoo.co.uk

Department of Veterinary Pathology, University of Abuja, Abuja, Nigeria concentrations and bioaccumulation status of some heavy metals and their toxic effects in fish from this big aquatic ecosystem because of the large areas it traverses. The presence of some heavy metals has been reported in Tiga dam, Nigeria [8]. Similarly, some heavy metals have also been reported in the bones, muscles and gills of Tilapia and Clarias lazera inhabiting the dam [9]. However, there is currently no report on the assessment of heavy metals bioaccumulation in Tiga dam and their pathological implications in the exposed fish. Auchenoglanis occidentalis, which is of commercial importance in Nigeria, is one of the fish that are normally caught from Tiga dam for human consumption. That is why this study aimed to conduct the assessment of heavy metals concentration in Tiga dam, Nigeria vis-à-vis their bioaccumulation and pathological alterations in A. occidentalis harvested from it.

\section{Materials and methods \\ Study area}

Tiga dam is situated in Kano State, which is in northern part of Nigeria as shown in Fig. 1. It is located at Latitude $11^{\circ} 15$ to $11^{\circ} 29^{\prime \prime} \mathrm{N}$ and Longitude $8^{\circ} 16$ to $8^{\circ} 38^{\prime \prime} \mathrm{E}$. The dam measures about $40.40 \mathrm{~km}$ in length, $24.40 \mathrm{~km}$ in width and $40.00 \mathrm{~m}$ in depth with a surface area of $178.00 \mathrm{~km}^{2}$, 


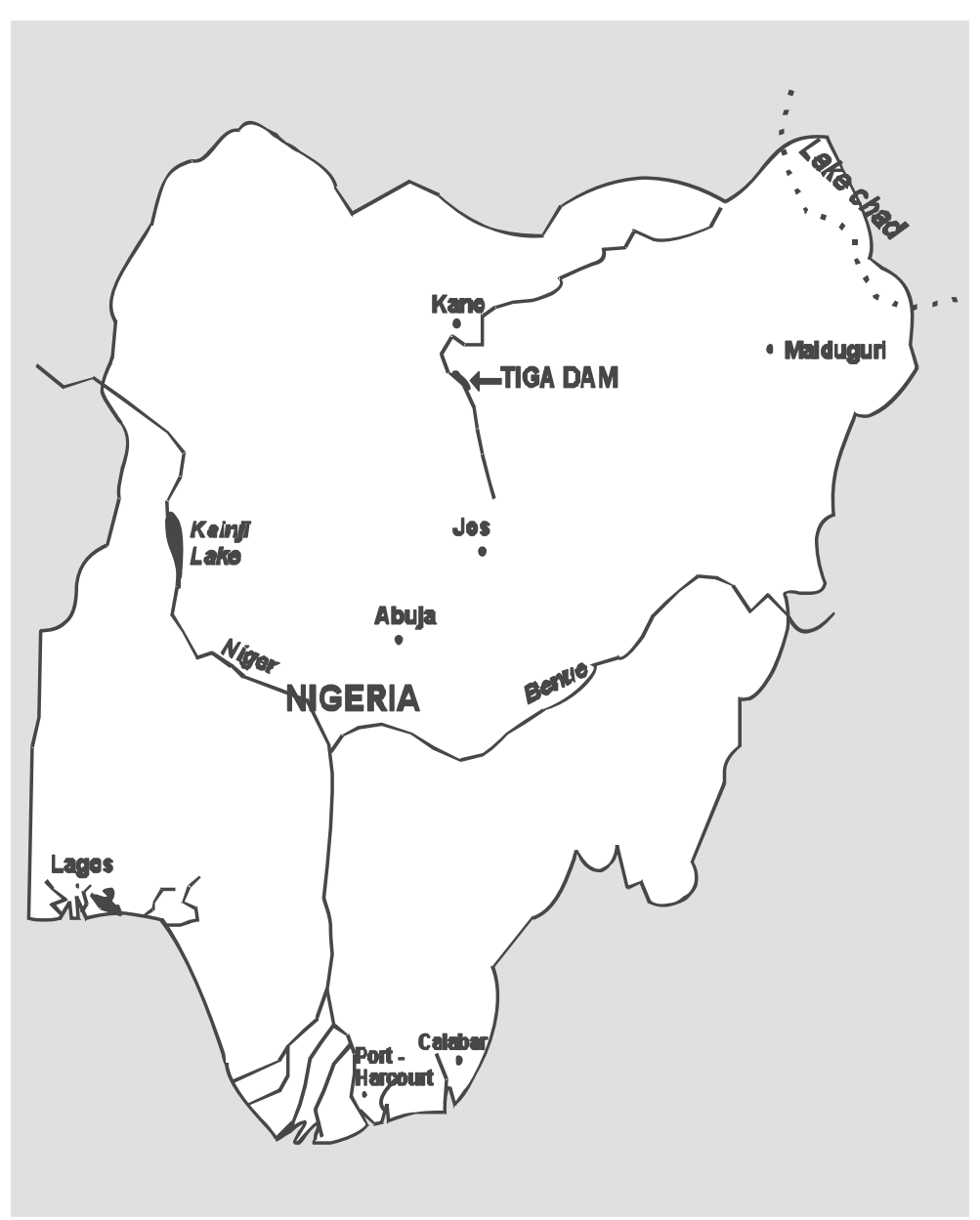

Fig. 1 The map of Nigeria showing Tiga dam

including a storage capacity of about $1978.49 \times 10^{6} \mathrm{~m}^{3}$ litres of water [10], respectively.

\section{Water and fish sampling}

A total of 13 water samples were collected once a week from different locations in Tiga dam over a 4-month period between September and December, 2009. Similarly, a total of 16 A. occidentalis of $435.60 \pm 24.13 \mathrm{~g}$ mean weight and $31.41 \pm 2.28 \mathrm{~cm}$ mean length were collected once a week from the dam by local fishermen using dug-out canoes and nets over the same period. The fish were kept in containers with fresh water from Tiga dam, Nigeria immediately upon their capture and then sampled within three hours as suggested by [11].

\section{Heavy metal analysis}

The concentration of cadmium $(\mathrm{Cd})$, lead $(\mathrm{Pb})$, zinc $(\mathrm{Zn})$ and iron $(\mathrm{Fe})$ in the water and in the liver of the sampled A. occidentalis were determined using Atomic absorbance spectrophotometer (AA, 6800) based on Beer-Lambert's law. The liver was initially digested prior to metal analysis.
One gramme of the harvested liver tissue was put into a crucible and dry ashed in a furnace at $550{ }^{\circ} \mathrm{C}$ for one hour [12] before the addition of $5 \mathrm{ml}$ of concentrated nitric acid and $15 \mathrm{ml}$ of concentrated hydrochloric acid $(1: 3 \mathrm{v} / \mathrm{v})$ in an Aqua regia digestion [13]. The mixture was then heated at $100{ }^{\circ} \mathrm{C}$ to about dryness on a hot plate before adding $10 \mathrm{ml}$ of distilled water and filtered warm into a $100 \mathrm{ml}$ volumetric flask, which was later made up to the mark with distilled water [14]. The absorption wavelength used for the measurements and detection limits of the metals are as shown in Table 1.

\section{Bioaccumulation factor}

Bioaccumulation factor was determined on the basis of the ratio of a particular metal concentration in any organ and its dissolved concentration in the water as described by [15].

\section{Histopathological examination}

The fish were euthanized with $40 \%$ ethyl alcohol before individually excising their gills, liver and kidney for 
Table 1 The absorption wavelength and detection limit of zinc, cadmium, lead and iron under investigation

\begin{tabular}{llll}
\hline Metal & Symbol & $\begin{array}{l}\text { Absorbance } \\
\text { wavelength }(\mathrm{nm})\end{array}$ & $\begin{array}{l}\text { Detection } \\
\text { limit }(\mathrm{ppm})\end{array}$ \\
\hline Zinc & $\mathrm{Zn}$ & 213.9 & - \\
Cadmium & $\mathrm{Cd}$ & 228.8 & 0.0028 \\
Lead & $\mathrm{Pb}$ & 217.0 & 0.02 \\
Iron & $\mathrm{Fe}$ & 248.3 & 0.59 \\
\hline
\end{tabular}

histopathological processing and examinations. Tissues were fixed in $10 \%$ formal saline prior to paraffin embedding, sectioning at $5 \mu \mathrm{m}$ and then staining with haematoxylin and eosin $[16,17]$. The severity of the lesions in each of the organ was determined semiquantitatively by modifying the degree of tissue changes (DTC) method described by [18]. Alterations in each of the organ were classified in progressive order based on the formula: $\mathrm{DTC}=(1 \times \Sigma I)+(10 \times \Sigma I I)+(100 \times \Sigma I I I)$ after screening the number of tissue lesions in stages $I$, $I I$ and III for that particular organ. Alterations that do not alter the normal functioning of the organ were classified as Stage $I$ alterations. Those alterations that were more severe and impaired the normal functioning of the organ were classified as stage $I I$ alterations. Similarly, severe alterations that induce irreparable tissue damage were classified as stage III alterations. Organs with numerical values ranging from $0-10$ were graded as normal tissue, 11 - 20 as mildly damaged tissue, 21 - 50 as moderately damaged tissue, 51 - 100 as severely damaged tissue while those with numerical values above 100 were graded as irreversibly damaged tissue.

\section{Statistical analysis}

GraphPad software programme (GraphPad Prism, version 4.0, San Diego, California, USA. www.graphpad.com) was used to determine the mean $( \pm$ sem), which were further subjected to one-way analysis of variance (ANOVA), Student's $t$-test and Tukey's tests for comparing differences between the means for statistical significance $(p<0.05)$.
Table 3 Histopathological lesions in the gills, liver and kidney of Auchenoglanis occidentalis sampled from Tiga dam, Nigeria

\begin{tabular}{|c|c|c|c|}
\hline \multirow[t]{3}{*}{ Stage } & \multicolumn{3}{|c|}{ Degree of tissue change } \\
\hline & Gills & Liver & Kidney \\
\hline & Alteration \% & Alteration \% & Alteration \% \\
\hline \multirow[t]{6}{*}{1} & $\begin{array}{l}\text { Epithelial } \\
\text { proliferation } 50.0\end{array}$ & Vacuolation 12.5 & Vacuolation 18.8 \\
\hline & $\begin{array}{l}\text { Epithelial } \\
\text { detachment } 43.8\end{array}$ & \multirow[t]{5}{*}{ Cellular infiltration 18.8} & \multirow[t]{5}{*}{$\begin{array}{l}\text { Widened bowman's } \\
\text { capsule } 12.5\end{array}$} \\
\hline & $\begin{array}{l}\text { Lamellar } \\
\text { oedema } 56.3\end{array}$ & & \\
\hline & $\begin{array}{l}\text { Mucous cells } \\
\text { proliferation } 12.5\end{array}$ & & \\
\hline & $\begin{array}{l}\text { Mucous cells } \\
\text { hypertrophy } 12.5\end{array}$ & & \\
\hline & $\begin{array}{l}\text { Partial lamellar } \\
\text { fusion } 50.0\end{array}$ & & \\
\hline \multirow[t]{3}{*}{ /I } & $\begin{array}{l}\text { Complete lamellar } \\
\text { fusion } 18.8\end{array}$ & \multirow[t]{3}{*}{ Haemorrhage 12.5} & \multirow[t]{3}{*}{ Haemorrhage 12.5} \\
\hline & Aneurysm 43.8 & & \\
\hline & Haemorrhage 12.5 & & \\
\hline \multirow[t]{3}{*}{ III } & & \multirow[t]{3}{*}{ Hepatic necrosis 12.5} & $\begin{array}{l}\text { Glomerular } \\
\text { necrosis } 6.3\end{array}$ \\
\hline & & & $\begin{array}{l}\text { Tubular } \\
\text { necrosis } 6.3\end{array}$ \\
\hline & & & $\begin{array}{l}\text { Interstitial } \\
\text { necrosis } 12.5\end{array}$ \\
\hline
\end{tabular}

\section{Results and discussion}

The mean concentrations of $\mathrm{Pb}, \mathrm{Cd}, \mathrm{Zn}$ and $\mathrm{Fe}$ in the dam water as well as in the liver of the sampled $A$. occidentalis and their bioaccumulation factors were determined as shown in Table 2. The concentrations of $\mathrm{Pb}, \mathrm{Cd}, \mathrm{Zn}$ and $\mathrm{Fe}$ were higher in the liver of $A$. occidentalis than their concentrations in the water of the dam in affirmation of an earlier report by [19] that lower concentrations of metals are generally recorded in water compared to fish tissues. These might be attributed to the pollution of the fish's external environment and the rate of ingestion and excretion in the exposed fish [20]. The significant $(P<0.05)$

Table 2 Mean concentrations of lead, cadmium, zinc and iron in the water and liver of Auchenoglanis occidentalis sampled from Tiga dam, Nigeria ( $n=13$ for water; $n=16$ for fish)

\begin{tabular}{|c|c|c|c|c|c|}
\hline Parameters & Lead $(\mathrm{Pb})$ & Cadmium (Cd) & Zinc (Zn) & Iron (Fe) & References \\
\hline Water concentration (ppm) & $0.33 \pm 0.03$ & $0.02 \pm 0.00^{*}$ & $0.01 \pm 0.00^{* *}$ & $2.61 \pm 0.07^{* *}$ & This study \\
\hline Liver concentration (ppm) & $0.35 \pm 0.04$ & $0.04 \pm 0.00^{*}$ & $2.17 \pm 0.30^{* *}$ & $11.66 \pm 1.32^{* *}$ & This study \\
\hline Bioaccumulation factor & 1.06 & 2.00 & 217.00 & 4.46 & This study \\
\hline \multirow[t]{2}{*}{ Maximum acceptable water limit (ppm) } & 0.01 & 0.003 & 3.00 & 0.30 & NIS (2007) \\
\hline & 0.01 & 0.01 & 5.00 & 0.30 & WHO (2003) [24] \\
\hline Maximum acceptable liver limit $\left(\mathrm{mgkg}^{-1}\right)$ & 0.01 & 0.01 & 5.00 & 0.30 & WHO (2003) [24] \\
\hline
\end{tabular}

*:Values within the column are statistically significant at $p<0.0056$ 


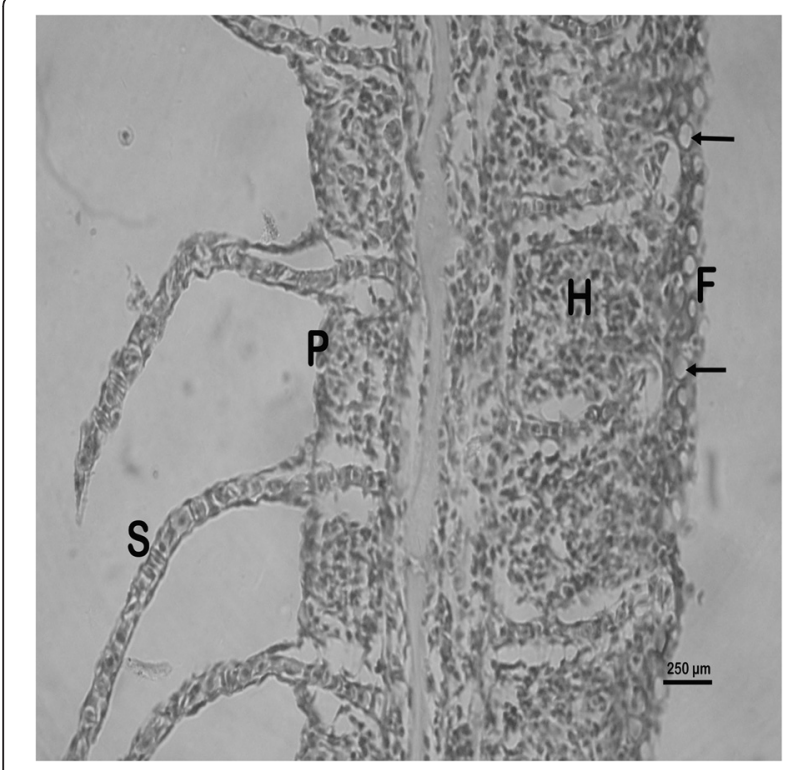

Fig. 2 Photomicrograph of the gill of Auchenoglanis occidentalis sampled from Tiga dam, Nigeria. Note the primary lamellar ( $P)$, secondary lamellar (S), epithelial hyperplasia $(H)$, complete lamellae fusion (F) and mucous cells hyperplasia and hypertrophy (arrows) differences between the concentrations of the metals in the dam's water and also in the liver of A. occidentalis might be due to varying levels of the pollution of the dam with the metals. Lead might have come from sewage and agricultural wastes discharged into the dam [4]. Similarly, $\mathrm{Cd}$ might have come from natural sources and/or as runoff from agricultural soils around the dam where

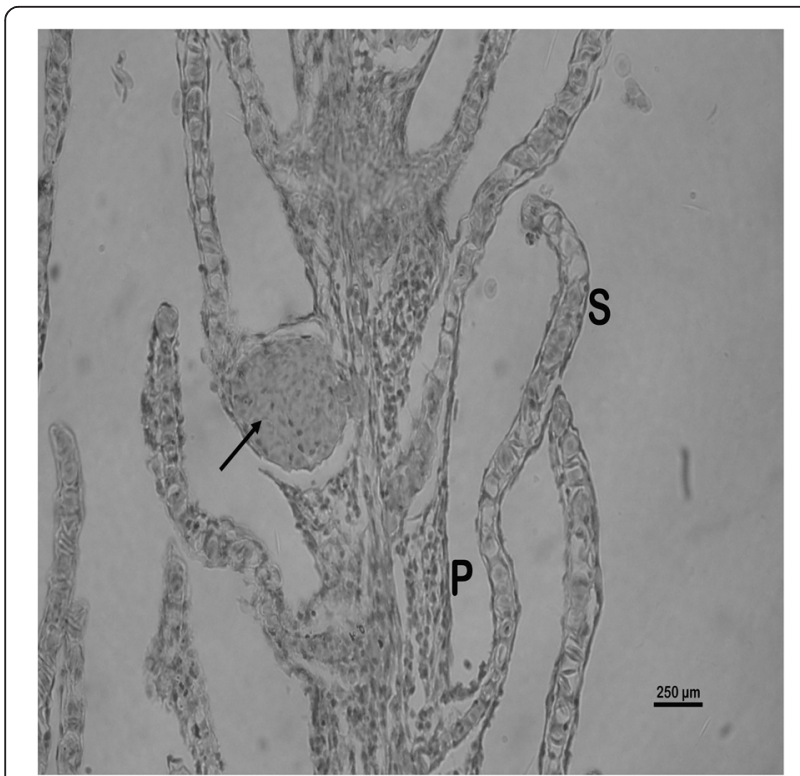

Fig. 3 Photomicrograph of the gill of Auchenoglanis occidentalis sampled from Tiga dam, Nigeria. Note the primary lamellar (P), secondary lamellar (S) and aneurysm (arrow)

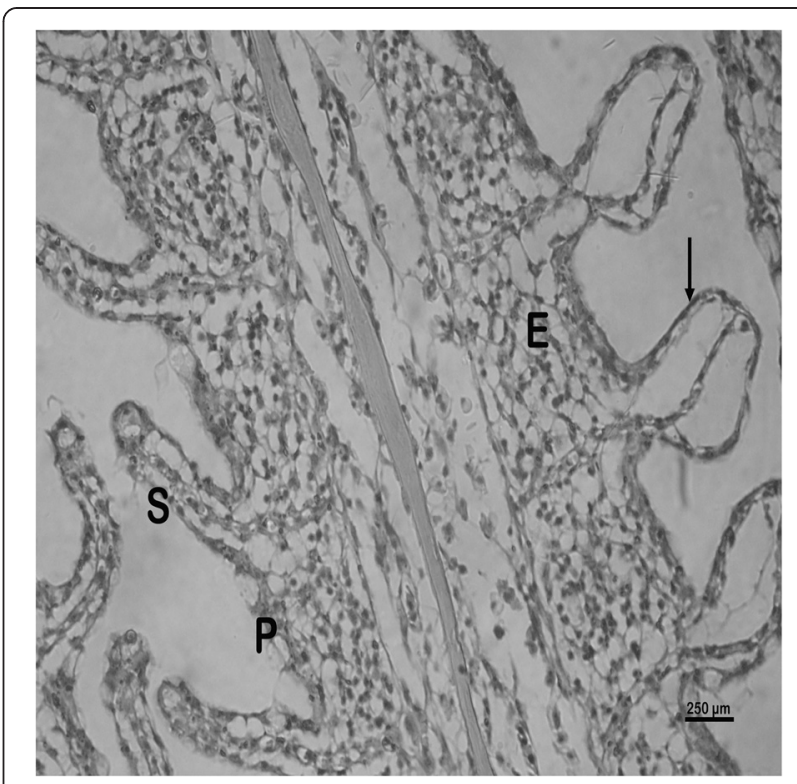

Fig. 4 Photomicrograph of the gill of Auchenoglanis occidentalis sampled from Tiga dam, Nigeria. Note the primary lamellar (P), secondary lamellar (S), lamellae oedema (E) and epithelial detachment (arrow)

phosphate fertilizers have been in use [21, 22]. However, $\mathrm{Zn}$ might have arisen from the mining activities within the Jos plateau, which is the main source of the dam's water along with run-offs from around it. Although lead was the least bioaccumulated metal, its water and liver concentrations were higher than the recommended maximum

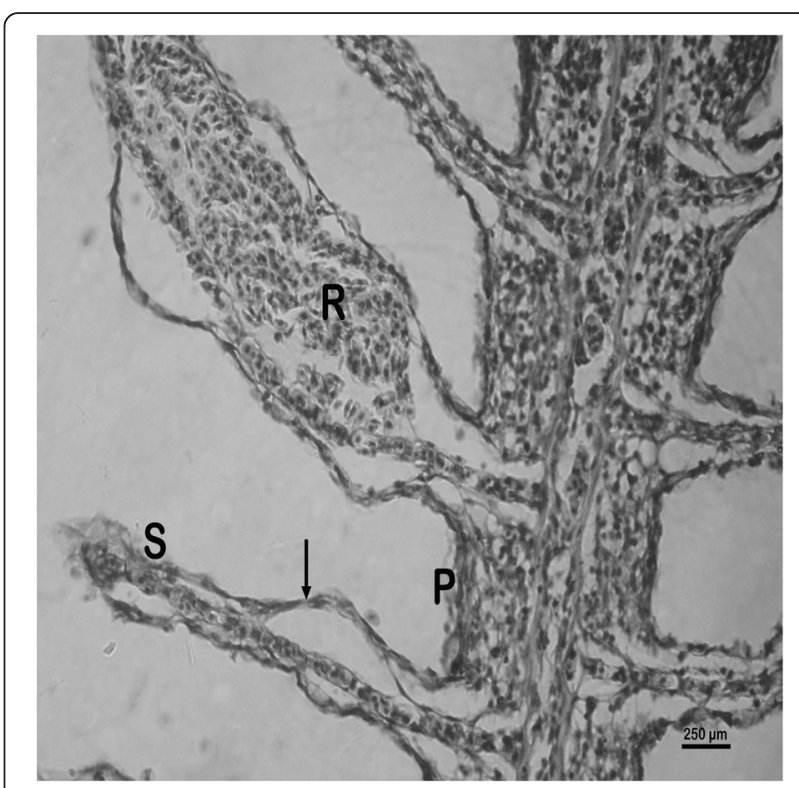

Fig. 5 Photomicrograph of the gill of Auchenoglanis occidentalis sampled from Tiga dam, Nigeria. Note the primary lamellar (P), secondary lamellar (S), haemorrhage (R) and epithelial detachment (arrows) 


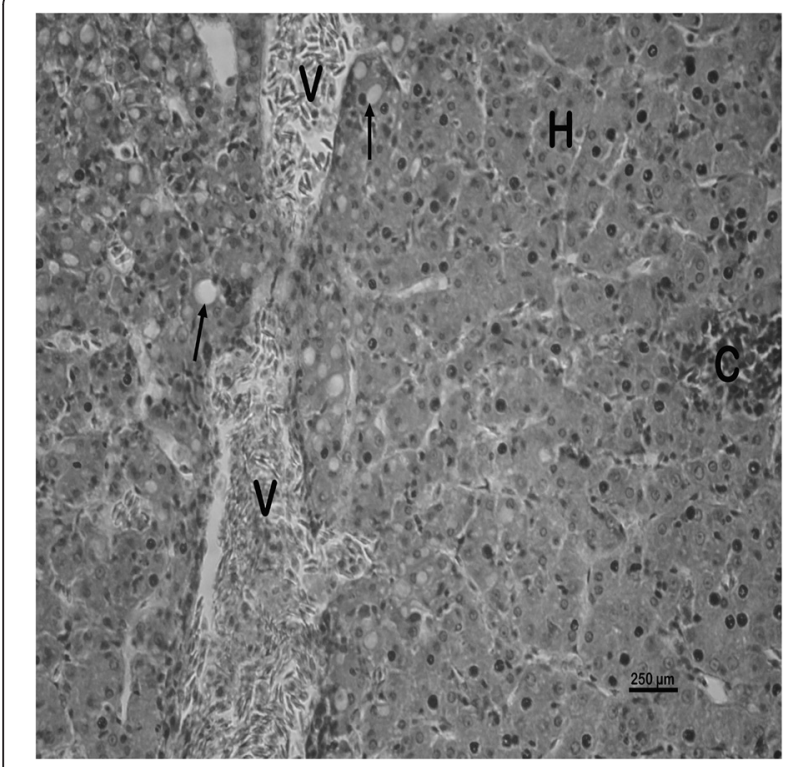

Fig. 6 Photomicrograph of the liver of Auchenoglanis occidentalis sampled from Tiga dam, Nigeria. Note the hepatocyte $(H)$, central vein (V), cellular infiltration (C) and vacuolations (arrows)

acceptable limits of $0.01 \mathrm{mgkg}^{-1}$ for water and $0.01 \mathrm{mgkg}^{-1}$ for fish tissues [23, 24]. Similarly, the concentrations of $\mathrm{Cd}$ and Fe in Tiga dam, Nigeria and in the liver of the fish were also above the maximum acceptable limits recommended by $[23,24]$ for both water and fish tissues, respectively. High concentrations of $\mathrm{Pb}$ and $\mathrm{Cd}$ in both the dam's water and in the liver of the fish tended towards toxic concentrations. This is because although $\mathrm{Pb}$ and $\mathrm{Cd}$ are

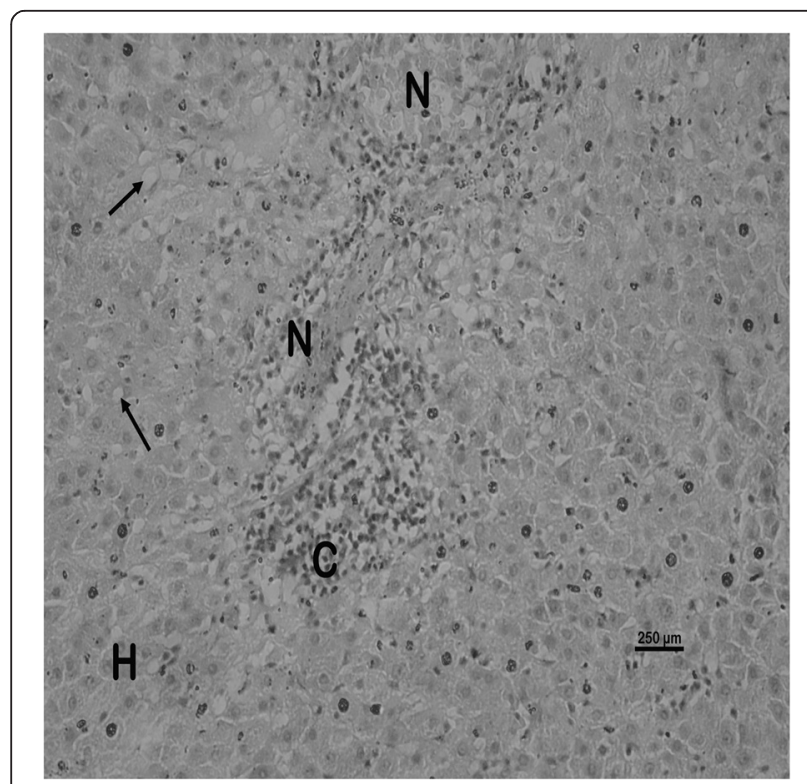

Fig. 7 Photomicrograph of the liver of Auchenoglanis occidentalis sampled from Tiga dam, Nigeria. Note the hepatocyte $(\mathrm{H})$, cellular infiltration (C), necrosis ( $\mathrm{N}$ ) and vacuolations (arrows)

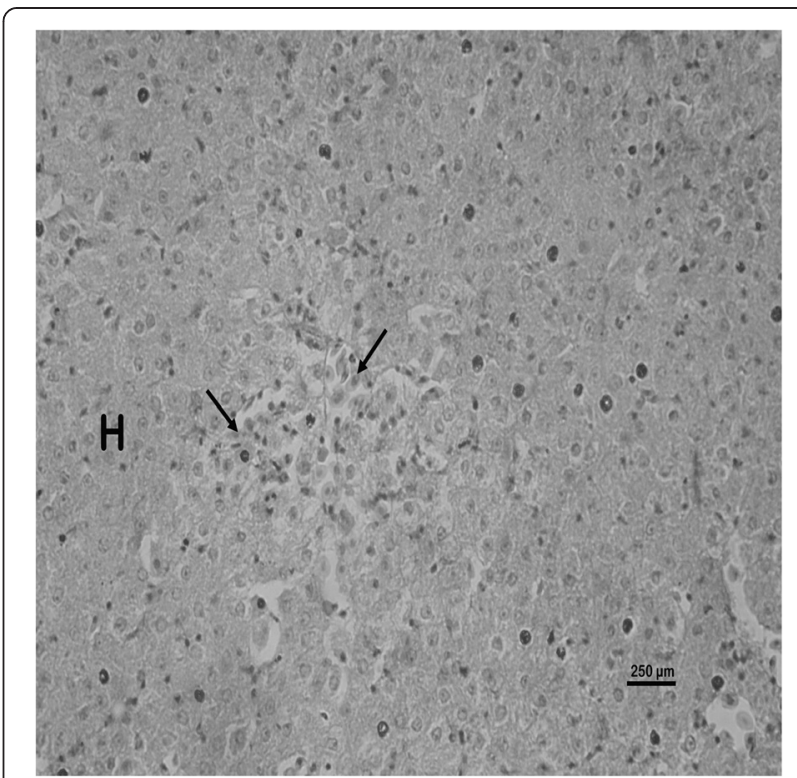

Fig. 8 Photomicrograph of the liver of Auchenoglanis occidentalis sampled from Tiga dam, Nigeria. Note the hepatocyte $(H)$ and haemorrhage (arrows)

non-essential for metabolic activity, they exhibit toxic properties even at trace concentrations [25]. The toxic effect of $\mathrm{Pb}$ and $\mathrm{Cd}$ might be in the form of severe membrane integrity damage with subsequent loss of membranebound enzyme activity resulting in cellular death [26]. Iron is found in natural freshwaters and has no health guideline value but high concentration in water may give rise to consumer complaints [27]. Although zinc was the

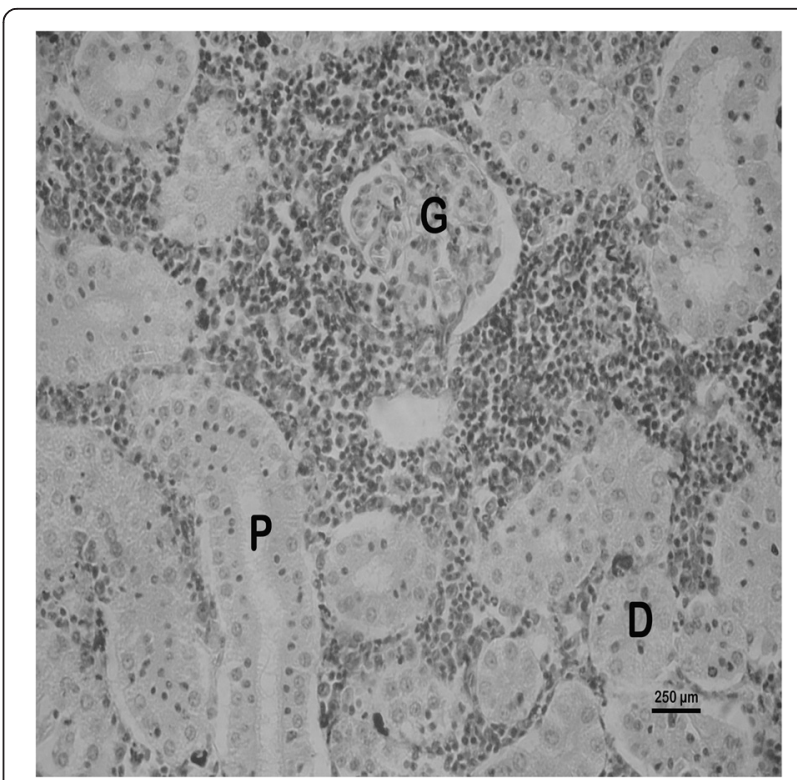

Fig. 9 Photomicrograph of the kidney of Auchenoglanis occidentalis sampled from Tiga dam, Nigeria. Note the glomerulus (G), proximal tubule $(P)$ and the distal tubule (D) 


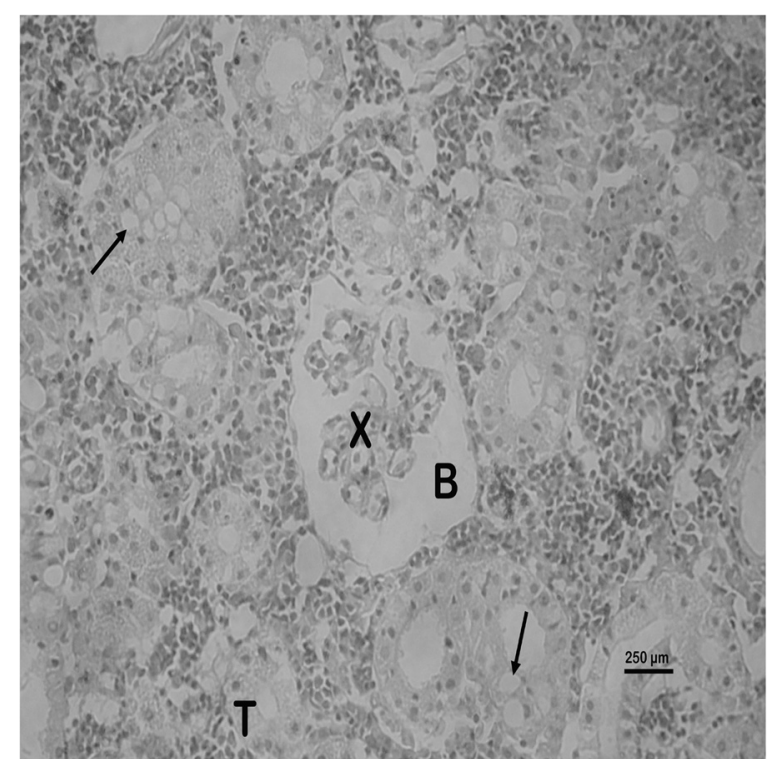

Fig. 10 Photomicrograph of the kidney of Auchenoglanis occidentalis sampled from Tiga dam, Nigeria. Note glomerular necrosis $(X)$, tubular necrosis (T), widened Bowman's space (B) and tubular vacuolations (arrows)

most bioaccumulated metal, its water and liver concentrations were below the recommended maximum acceptable limits [23, 24]. However, zinc and iron are essential metals for the growth and well-being of organisms but they may bioaccumulate beyond the optimum threshold concentrations to becoming hazardous and toxic [5]. This is because zinc is reported to be potentially toxic to fish [28] and may cause structural damage in the exposed fish [29].

The nature and severity of the observed lesions in the gills, liver and kidney of the sampled fish are as shown in Table 3 while the observed histopathological alterations in the gills, liver and kidney are also presented in Figs. 2, $3,4,5,6,7,8,9,10,11$, respectively. The degree of tissue change (DTC) in the gill of the sampled fish was calculated to be $9.75 \pm 3.00$ while that in the liver of the fish was $14.06 \pm 9.46$. Similarly, the DTC in the kidney of the sampled fish was $26.63 \pm 11.16$. However, there were no significant $(\mathrm{p}>0.05)$ differences in the DTC between the gills, liver and kidney of exposed fish. The observed epithelial proliferation (hyperplasia) and the detachment of the gill epithelial cells along with the partial to complete lamellar fusion are non-specific responses of the gills to toxic irritants [30], which were natural attempts by the exposed fish to increase the diffusion distance between their blood and the toxic external environment [31-33]. Increased permeability of the gill capillary walls following vessel dilatation at the site of toxic damage might be responsible for the observed lamellar oedema [34]. The observed mucous cells proliferation and hypertrophy, which leads to increased mucous secretion, were

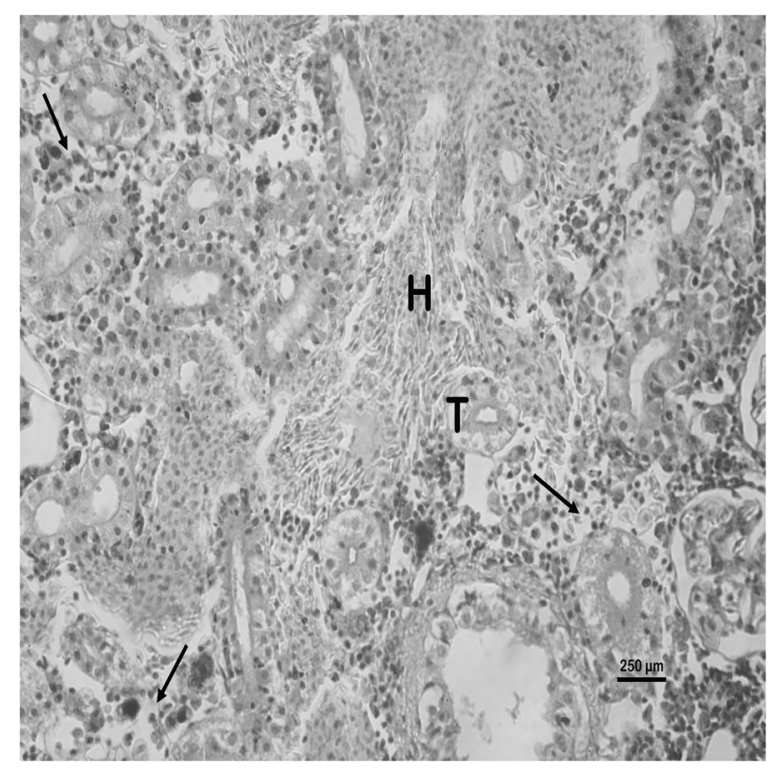

Fig. 11 Photomicrograph of the kidney of Auchenoglanis occidentalis sampled from Tiga dam, Nigeria. Note haemorrhage $(H)$, tubular necrosis ( $\mathrm{T}$ ) and interstitial necrosis (arrows)

protective defence responses to coat absorptive surfaces [30] in line with the fact that increased mucous secretions are more often associated with heavy metal exposure than with organic pollutant exposures [30].

The observed hepatic vacuolations may be due to lipid and/or glycogen deposition [35] suggestive of metabolic disorders as a consequence of the exposure to toxic agents [36]. Hepatic cellular infiltrations were suggestive of inflammatory responses in the affected liver. The observed haemorrhage might be due to the toxic damage to the liver of the exposed fish while the necrotic changes in the affected liver were a consequence of the toxic effects of the metals [6]. These hepatic lesions might probably be due to the primary function of the liver in the metabolism and excretion of toxicants where some morphological changes do occur in the process [37]. Although liver lesions are not usually specific to pollutants, a casual relationship between metal concentrations and fish liver lesions has been established [38]. This might be why the estimated DTC in the liver of the exposed fish suggested mild organ damage. The choice of the gills and the liver as monitor tissues for this study was due to their known functions in the uptake, bioaccumulation and the detoxification of environmental pollutants [39-41]. Similar changes have been reported in the gills and liver of exposed fish [42, 43].

The observed tubular vacuolations in the kidney of the sampled fish were indicative of fatty degenerative changes due to metabolic disorders. This is because cytoplasmic vacuolations are known to occur in parenchyma cells 
(hepatic cells, kidney tubular epithelium and myocardial cells) in cases of fatty overload [44]. The observed tubular necrosis was indicative of exposure to toxic chemical substances [45]. These changes are in agreement with the fact that heavy metals are known to cause cellular damages in the kidney of exposed fish [46, 47]. The observed histopathological lesions in the gills, liver and kidney of the exposed $A$. occidentalis were similar to lesions reported in same organs of Oreochromis niloticus exposed to some heavy metals [48].

\section{Conclusion}

The increased water concentrations of $\mathrm{Pb}, \mathrm{Fe}$ and $\mathrm{Cd}$ far above the maximum acceptable limit and their bioaccumulation in the liver of the sampled $A$. occidentalis were suggestive of heavy metals pollution. This is further reinforced by the observed alterations in the gills, liver and kidney of the sampled $A$. occidentalis. This revelation call for great concerns and highlight the need for constant monitoring of this huge and important water body in order to safeguard the health and lives of organisms, animals and people associated with it.

\section{Competing interests}

The author declares that he has no competing interests.

\section{Author's contributions}

The author was responsible for the preparation and the vetting of the final manuscript and can attest to the validity and legitimacy of the data so presented.

\section{Acknowledgements}

I acknowledge the valuable contributions of Mr. Abdulsalam Umar, Mr. Aniete Sunday Williams and Mr. Femi Akolo in the actualization of the work.

Received: 15 July 2013 Accepted: 19 September 2015

Published online: 06 October 2015

\section{References}

1. Alinnor IJ, Obiji IA. Assessment of trace metal composition in fish samples from Nworie River. Pakistan J Nutri. 2010;9(1):81-5.

2. Vander Oost R, Beyer J, Vermeykebm NPE. Fish bioaccumulation and biomarkers in environmental risk assessment: a review. Environ Toxicol Pharmacol. 2003;13:57-149.

3. Al-Attar AM. Changes in haematological parameters of the fish, Oreochromis niloticus treated with sublethal concentrations of cadmium. Pakistan J Biol Sci. 2005;8(3):421-4.

4. El-Nagger AM, Mohamoud SA, Tayel SI. Bioaccumulation of some heavy metals and histopathological alterations in liver of Oreochromis niloticus in relation to water quality at different localities along the River Nile, Egypt. World J Fish Mar Sci. 2009;1(2):105-14.

5. Puttaiah ET, Kiran BR. Heavy metal transport in a sewage fed Lake of Karnataka, India. In: Edited by Sengupta M, Dalwani R. Proceedings of Taal2007. The 12th World Lake Conference; Jaipur, India 2008.

6. Mohamed FAS. Bioaccumulation of selected metals and histopathological alterations in tissues of Oreochromis niloticus and Lates niloticus from Lake Nasser, Egypt. Global Vet. 2008;2(4):205-18.

7. Forstner V, Wittman GTW. Metal pollution in the aquatic environment. New York: Springer-Verlag, Berlin Heidelberg; 1986.

8. Ayodele JT, Abubakar M. Chromium and copper in water, sediments and their bioaccumulation by freshwater bivalves in Tiga dam, Nigeria. J Environ Sci. 2001;5(12):177-84.

9. Sani U. Determination of some heavy metals concentrations in the tissues of tilapia and catfishes. Biokemistri. 2011;23(2):73-80.
10. Ita EO. Aquatic plants and wetlands wildlife resources of Nigeria. FAO corporate document repository. CIFA Occasional Paper No. 21.1994. [http://www.fao.org/docrep/005/t3660e/t3660E00.htm\#TOC] Accessed: November 8, 2010

11. Kurtović B, Teskeredžić E, Teskerdžić Z. Histological comparism of spleen and kidney from farmed and wild European sea brass (Dicentrarchus labrax L.). Acta Adriat. 2008;49(2):147-54.

12. Azcue J, Mudroch A. Comparison of different washing, ashing and digestion methods for the analysis of trace elements in vegetation. Intern J Anal Chem. 1994;12:211-21.

13. Mcgrath SP, Cunliffe $\mathrm{CH}$. A simplified method for the extraction of the metals in sewage sludge on soils, microorganisms and plants. J Ind Microbiol. 1995;14:94-104.

14. Van Loon JC, Lichwa J. A study of the atomic absorption determination of some important heavy metals in fertilizers and domestic sewage plant sludges. Environ Lett. 1973;4(1):1-8.

15. Aboul Ezz AS, Abdel-Razek SE. Heavy metal accumulation in the Tilapia niloticus L. and in the water of Lake Manzalah. Egypt J Appl Sci. 1991;6(6):37-52

16. Roberts RJ. The patho-physiology and systemic pathology of teleost. In: Roberts RJ, editor. Fish Pathology. London: Bailliére Tindall; 1978.

17. Bancroft JD, Cook HC. Manual of histological techniques and their diagnostic application. London: Churchill Livingstone; 1994.

18. Poleksic $V$, Mitrovic-Tutundzic $V$. Fish gills as a monitor of sublethal and chronic effects of pollution. In: Muller R, Llyod R, editors. Sublethal and chronic effects of pollutants on freshwater fish. Oxford: Fishing News books; 1994.

19. Olaifa FE, Olaifa AK, Adelaja AA, Owolabi AG. Heavy metals contamination of Clarias gariepinus from a lake and fish farm in Ibadan, Nigeria. Afri J Biomed Res. 2004;7:145-8.

20. Adeyeye El, Akinyugha NJ, Fesobi ME, Tenabe VO. Determination of some metals in Clarias gariepinus (Cuvier and valenciennes), Cyprinus carpio (L) and Oreochromis niloticus (L.) fishes in a polyculture freshwater pond and their environments. Aquaculture. 1996;147:205-14.

21. Stoeppler M. Cadmium. In: Merian E, editor. Metals and their compounds in the environment: occurrence, analysis and biological relevance. New York: $\mathrm{CCH} ; 1991$.

22. Dimari GA, Abdulrahman JC, Garba ST. Metal concentrations in tissues of Tilapia galli, Clarias lazera and Osteoglosidae caught from Alau dam, Maiduguri, Borno State, Nigeria. Am J Environ Sci. 2008;4:373-9.

23. Nigerian Industrial Standard (NIS 554: 2007). Nigerian standard for drinking water quality.[http://www.unicef.org/nigeria/ ng_publication_Nigerian_Standard_for_Drinking_Water_Quality.pdf] Accessed: October 10, 2010

24. WHO. Malathion in drinking water. Background Document for Preparation of WHO guidelines for drinking water quality. Geneva: World Health organization (WHO/SDE/WSH/03.04/103); 2003.

25. FAO. Committee for inland fisheries of Africa: Report of the third session of the working party on pollution and fisheries. 25-29 November 1991; Accra, Ghana. FAO Fisheries Report No. 471. 1992.

26. Younes N, Siegers CP. Interrelation between lipid peroxidation and other hepatotoxic events. Biochem Pharmacol. 1984;33:2001-3.

27. WHO. Guidelines for drinking water quality, vol. 1. Thirdth ed. Geneva: World Health Organization; 2004.

28. Everall NC, MacFarlan NAA, Sedgwick RW. The interaction of water hardness and $\mathrm{pH}$ with the acute toxicity of zinc to the brown trout, Salmo trutta L. J Fish Biol. 1989:35:27-36.

29. Tuurala H, Soivio A. Structural and circulatory changes in the secondary lamella of salmo gaidneri gills to dehydioabietic acid and zinc. Aquat Toxicol. 1982;2:21-9.

30. Mallat J. Fish gill structural changes induced by toxicants and other irritants: a statistical review. Can J Fish Aquat Sci. 1985;42:630-48.

31. Laurén DJ, McDonald DG. Effects of copper on branchial ionoregulation in the rainbow trout, Salmo gairdneri Richardson: modulation by water hardness and pH. J Comp Physiol B. 1985;155:675-44.

32. Arellano JM, Storch V, Sarasquete C. Histological changes and copper accumulation in liver and gills of the Senegalese sole, Solea senegalensis. Ecotoxicol Environ Saf. 1999;44:62-72.

33. Abdul-Moneim AM, NM A s, Khadre SEM, Abdul-Kader HH. Physiological and histopathological effects in catfish (Clarias lazera) exposed to dyestuff and chemical wastewater. Int J Zool Res. 2008;4(4):189-202. 
34. Olurin K, Olojo E, Mbaka G, Akindele A. Histopathological responses of the gill and liver tissue of Clarias gariepinus fingerlings to the herbicide, glyphosate. Afr J Biotechnol. 2006:5:2480-7.

35. Myers MS, Rhodes LD, McCain BB. Pathologic anatomy and pattern of occurrence of hepatic neoplasm, putative preneoplastic lesions and other idiopathic hepatic conditions in English sole (Parohrys vetulus) from Puget Sound Washington. J Nat Cancer Inst. 1987;78:333-63.

36. Pacheco M, Santos MA. Biotransformation, genotoxic and histopathologica effects of environmental contaminants in European eel (Anguilla Anguilla L.). Ecotoxicol Environ Saf. 2002;53:331-47.

37. Rocha E, Monteiro RAE. Histology and cytology of fish liver: a review. In: Saksena DN, editor. Ichthyology: Recent Research Advances. Enfield, New Hampshire: Science Publishers; 1999.

38. Au DWT. The application of histopathological biomarkers in marine pollution monitoring: A review. Mar Pollut Bull. 2004;48:817-34.

39. Hamilton SJ, Mehrle PM. Metallothionein in fish: Review of its importance in assessing stress from metal contaminants. Trans Am Fish Soc. 1986;115:596-609.

40. Romeo M, Siau Y, Sidoumonu Z, Gnassia-Barelli M. Heavy metal distribution in different fish species from the Mauritania coast. Sci Total Environ. 1999;132:169-75.

41. Triebskorn R, Adam S, Casper H, Honnen W, Pawert M, Schramm M. Biomarkers as diagnostic tools for evaluating toxicological effects of past water quality conditions on stream organisms. Ecotoxicol. 2002;11:451-65.

42. Triebskorn R, Telcean I, Casper H, Farkas A, Sandus C, Stan G, et al. Monitoring pollution in River Mureş, Romania, Part II: Metal accumulation and histopathology in fish. Environ Monit Assess. 2008;141(1-3):177-88.

43. Gurcu B, Yildiz S, Basimo Y, Koca G, Koca S. Investigation of histopathological and cytogenic effects of heavy metals pollution on Cyprinus carpio (Linneaus, 1758) in the Gölmarmara Lake, Turkey. J Anim Vet Adv. 2010;9(4):798-808

44. Cabana EM. Cellular Degeneration and Infiltration. 2012 [http://www2.mozcom.com/ emcdvm/pathol.html] Accessed: November 20, 2010

45. Robbins SL. Pathological Basis of Disease. Philadelphia: W. B. Saunders Company; 1974.

46. Trump BF, Jones RT, Sahaphong S. Cellular effect of mercury on fish kidney tubules. In: Roberts RJ, editor. Fish pathology. London: Bailliére Tindall; 1989.

47. Gupta P, Srivastava N. Effects of sublethal concentrations of zinc on histological changes and bioaccumulation of zinc by kidney of fish Channa punctatus (Bloch). J Environ Biol. 2006;27:211-5.

48. Kaoud HA, El-Dahshan AR. Bioaccumulation and histopathological alterations of the heavy metals in Orechromis niloticus fish. Nature Sci. 2010:894(4):147-56.

\section{Submit your next manuscript to BioMed Central and take full advantage of:}

- Convenient online submission

- Thorough peer review

- No space constraints or color figure charges

- Immediate publication on acceptance

- Inclusion in PubMed, CAS, Scopus and Google Scholar

- Research which is freely available for redistribution 